\title{
Rhus javanica Linn protects against hydrogen peroxide-induced toxicity in human Chang liver cells via attenuation of oxidative stress and apoptosis signaling
}

\author{
CHANJIN YOON $^{1 *}$, SUSHRUTA KOPPULA $^{2 *}$, SEUNGHOON YOO $^{1}$, MUNJEONG YUM $^{1}$, \\ JINSEOUB KIM ${ }^{1}$, JAEDONG LEE ${ }^{3}$ and MINDONG SONG ${ }^{2}$ \\ ${ }^{1}$ Department of Applied Life Science, Graduate School of Konkuk University; \\ ${ }^{2}$ Department of Biotechnology, College of Biomedical and Health Sciences; ${ }^{3}$ Department of Internal Medicine, \\ School of Medicine, Konkuk University, Chungju, Chungbuk 380-701, Republic of Korea
}

Received March 22, 2015; Accepted October 29, 2015

DOI: $10.3892 / \mathrm{mmr} .2015 .4603$

\begin{abstract}
Rhus javanica Linn, a traditional medicinal herb from the family Anacardiaceae, has been used in the treatment of liver diseases, cancer, parasitic infections, malaria and respiratory diseases in China, Korea and other Asian countries for centuries. In the present study, the protective effects of $R$. javanica ethanolic extract (RJE) on hydrogen peroxide $\left(\mathrm{H}_{2} \mathrm{O}_{2}\right)$-induced oxidative stress in human Chang liver cells was investigated. The cell cytotoxicity and viability were assessed using a 3-(4,5-dimethylthiazol-2-yl)-2,5-diphenyltetrazolium bromide (MTT) assay. The activities of superoxide dismutase (SOD) and catalase (CAT) were measured using respective enzymatic kits. Cell cycle analysis was performed using flow cytometric analysis. The protein expression levels of $\mathrm{p} 53$, B-cell lymphoma (Bcl)-2, Bcl-2-associated X protein (Bax) and caspase- 3 were assessed by western blotting. Human Chang liver cells were treated with different concentrations $(0.1,0.3$ or $0.5 \mathrm{mg} / \mathrm{ml})$ of RJE, and were subsequently exposed to $\mathrm{H}_{2} \mathrm{O}_{2}(30 \mu \mathrm{M})$. Treatment with $\mathrm{H}_{2} \mathrm{O}_{2}(30 \mu \mathrm{M})$ significantly induced cytotoxicity $(\mathrm{P}<0.05)$ and reduced the viability of the Chang liver cells. However, pretreatment of the cells with RJE $(0.1,0.3$ or $0.5 \mathrm{mg} / \mathrm{ml})$ significantly increased the cell viability $(\mathrm{P}<0.001$ at $0.5 \mathrm{mg} / \mathrm{ml})$ in a concentration-dependent manner following $\mathrm{H}_{2} \mathrm{O}_{2}$ treatment. Furthermore, pretreatment with RJE increased the enzyme activities of SOD and CAT, and decreased the sub- $\mathrm{G}_{1}$ growth phase of the cell cycle in response to $\mathrm{H}_{2} \mathrm{O}_{2}$-induced oxidative stress
\end{abstract}

Correspondence to: Professor Mindong Song, Department of Biotechnology, College of Biomedical and Health Sciences, Konkuk University, U10 Danwol Dong Street, Chungju, Chungbuk 380-701, Republic of Korea

E-mail:minds@kku.ac.kr

*Contributed equally

Key words: Rhus javanica, Gallunt, antioxidant, caspase, hepatitis, apoptosis
( $\mathrm{P}<0.001$ at 0.3 and $0.5 \mathrm{mg} / \mathrm{ml} \mathrm{H}_{2} \mathrm{O}_{2}$ ). RJE also regulated the protein expression levels of p53, Bax, caspase-3 and Bcl-2. These results suggested that RJE may protect human Chang liver cells against oxidative damage by increasing the levels of antioxidant enzymes and regulating antiapoptotic oxidative stress mechanisms, thereby providing insights into the mechanism which underpins the traditional claims made for RJE in the treatment of liver diseases.

\section{Introduction}

The liver in vertebrates performs a number of vital functions, including metabolic and detoxification activities (1). Reactive oxygen species (ROS), generated under conditions of oxidative stress, are considered to be involved in the liver damage, which is induced under a variety of conditions, including alcohol abuse, fibrosis/cirrhosis, hepatocellular carcinoma, ischemia/reperfusion liver injury, paracetamol overdose and viral hepatitis (2). ROS are produced and degraded by all aerobic organisms, and exert beneficial effects, including cytotoxicity against bacteria and other pathogens during the maintenance of normal cell function. However, when ROS are present in excess, the state called 'oxidative stress' arises, which is associated with DNA damage, protein oxidation, carbonylation, lipid peroxidation, mitochondrial dysfunction, calcium homeostasis, actin reorganization, NAD depletion, impairment of energy metabolism and glutathione depletion in various cell types (3-5). To protect the human body against highly toxic ROS, various antioxidative stress mechanisms have been acquired, including an antioxidant defense system, which comprises intracellular antioxidant enzymes, including superoxide dismutase (SOD) and catalase (CAT), and glutathione $(4,5)$.

Hydrogen peroxide $\left(\mathrm{H}_{2} \mathrm{O}_{2}\right)$, one of the ROS molecules, is a by-product of oxidative stress, which is considered to act as a trigger of apoptosis in various cell types $(3,6)$. Previous studies reported that $\mathrm{H}_{2} \mathrm{O}_{2}$-induced apoptotic cell death was associated with caspase-3 (7). Various processes activate apoptosis and, in particular, caspase-3 activation may ensure the efficient completion of apoptotic cell death (7). Therefore, 
the prevention of oxidative stress may reduce apoptotic cell death.

Previous studies indicated that antioxidant herbal supplements are promising agents in therapeutic intervention strategies for the prevention and treatment of hepatic disorders $(8,9)$. Rhus javanica Linn ( $R$. javanica), from the family Anacardiaceae, is a deciduous, arborescent plant widely grown at the foot of mountains and in ravines in China, Korea and other Asian countries $(10,11)$. Traditionally, the fruit of the $R$. javanica plant has been used variously as an antidiarrheal, antitussive, anticoagulant and an antiperspirant. The leaves of $R$. javanica have been used as a detoxicant and as an antivenom for snake bites, and are renowned for their liver-protecting and antioxidative effects. The parasitic cocoon, termed 'Gallunt', on $R$. javanica, which contains gallotannin as its major component, also functions as an antidiarrheal, antibiotic and as a detoxicant, and exerts effects in hemostasis and in liver protection (12). Furthermore, it was reported that $R$. javanica has been widely used for centuries to treat cancer, dysentery, diarrhea, parasitic and bacterial infections in Korea, China, Japan and other Asian countries $(11,13,14)$. However, at present, the detailed mechanism underlying the action of the active agent(s) of $\mathrm{R}$. javanica, and its beneficial effects on $\mathrm{H}_{2} \mathrm{O}_{2}$-induced oxidative stress, remain to be fully elucidated. In the present study, the antioxidative properties of $R$. javanica were investigated, as well as the mechanism underlying these antioxidative effects in human Chang liver cells.

\section{Materials and methods}

Plant material. Dried plant material of $R$. javanica was purchased from a local herb market in Daejeon, South Korea. The plant material was authenticated by Professor Jung-Bo Kim, a taxonomist at Konkuk University, South Korea, and a voucher specimen (MDS-KKU/RJ2012) was deposited in our department herbarium at Konkuk University for future reference. The extraction was performed with the assistance of the Plant Extract Bank (Daejeon, South Korea). Briefly, the plant material (100 g) was extracted with $75 \%$ ethanol three times under reflux. The extract was filtered and concentrated by rotary evaporation at $50^{\circ} \mathrm{C}$ under a vacuum. The resulting residue was moved to a vacuum oven at $40^{\circ} \mathrm{C}$ and dried for $48 \mathrm{~h}$ to yield a solid extract $[R$. javanica ethanolic extract (RJE); yield, $10.344 \mathrm{~g}]$. RJE was dissolved in dimethylsulfoxide (DMSO; Sigma-Aldrich, St. Louis, MO, USA) and was subsequently diluted to the required concentrations $(0.1,0.3$ and $0.5 \mathrm{mg} / \mathrm{ml}$ ) with complete medium (Thermo Fisher Scientific, Inc., Waltham, MA, USA) for experimental use.

Cell culture. Human Chang liver cells were obtained from American Type Culture Collection (Manassas, VA, USA). Gibco $^{\mathrm{TM}}$ Dulbecco's modified Eagle's medium (DMEM), penicillin/streptomycin and the other materials required for the culture of cells were purchased from Thermo Fisher Scientific, Inc. All other chemicals were of analytical grade, or of the highest grade available commercially. Cell lines were maintained at $37^{\circ} \mathrm{C}$ in Gibco ${ }^{\mathrm{TM}}$ RPMI-1640 medium (Thermo Fisher Scientific, Inc.), supplemented with Invitrogen ${ }^{\mathrm{TM}} 10 \%$ fetal bovine serum, penicillin and streptomycin (100 units $/ \mathrm{ml}$;
Thermo Fisher Scientific, Inc.) in a humidified 5\% $\mathrm{CO}_{2} / 95 \%$ air atmosphere.

Determination of the ferric reducing antioxidant power (FRAP) assay. A FRAP assay was performed, according to the procedure described previously, with slight modifications (15). Briefly, FRAP reagent was prepared from $300 \mathrm{mM}$ acetate buffer (pH 3.6), $10 \mathrm{mM}$ 2,4,6-tripyridyl-s-triazine solution (Sigma-Aldrich) in $40 \mathrm{mM} \mathrm{HCl}$ and $20 \mathrm{mM}$ iron (III) chloride solution (Sigma-Aldrich) in the proportions of 10:1:1 (v/v), respectively. A total of $950 \mu 1$ FRAP reagent was added $50 \mu \mathrm{l}$ RJE. Following a period of $4 \mathrm{~min}$, the absorbance of the colored product (ferrous tripyridyltriazine complex) was measured at $593 \mathrm{~nm}$ using a Hewlett-Packard UV-Vis spectrophotometer (Palo Alto, CA, USA). The results were expressed as the $\mu \mathrm{M} \mathrm{Fe}(\mathrm{II}) / \mathrm{mg}$ dry mass, and were compared against those of butylated hydroxytoluene (BHT), which was used as a reference compound. All measurements were recorded in triplicate and the mean values were calculated.

2,2'-azinobis [3-ethylbenzthiazoline]-6-sulfonic acid(ABTS) free radical scavenging assay. The total antioxidant status of the RJE was measured using an ABTS assay (16). ABTS was dissolved in deionized water to a final concentration of $7 \mathrm{mM}$, and potassium persulfate (Sigma-Aldrich) was subsequently added to a concentration of $2.45 \mathrm{mM}$. The working solution was subsequently prepared by mixing the two stock solutions in equal quantities, and allowing them to react for $12 \mathrm{~h}$ at room temperature in the dark. The solution was subsequently diluted by mixing $1 \mathrm{ml}$ ABTS solution with $60 \mathrm{ml}$ methanol to obtain an absorbance of $0.706 \pm 0.001$ units at $734 \mathrm{~nm}$, as measured spectrophotometrically (Ultrospec 2100 Pro; GE Healthcare Bio-Sciences, Pittsburgh, PA, USA). Fresh ABTS solution was prepared for each assay. RJE (1 ml) was allowed to react with $1 \mathrm{ml}$ ABTS solution, and the absorbance was measured at $734 \mathrm{~nm}$ following an incubation of $7 \mathrm{~min}$ using the spectrophotometer. The ABTS scavenging capacity of the extract was compared with that of BHT. The total antioxidant activity was expressed as mM Trolox (SigmaAldrich) equivalent antioxidant capacity.

Determination of the total polyphenol content. The total phenolic acid content in RJE was estimated using a modified Folin-Ciocalteu method (17). An aliquot of the extract was mixed with $5 \mathrm{ml}$ Folin-Ciocalteu reagent (previously diluted with water at 1:10, v/v; Sigma-Aldrich) and $4 \mathrm{ml}$ (75 g/l) sodium carbonate solution (Sigma-Aldrich). The tubes were vortexed for $15 \mathrm{sec}$ and allowed to stand for $30 \mathrm{~min}$ at $40^{\circ} \mathrm{C}$ to enable color development. The absorbance was subsequently measured at $765 \mathrm{~nm}$ using the Hewlett-Packard UV-Vis spectrophotometer. The total polyphenol content in the RJE was compared with gallic acid equivalents (GAEs) using a gallic acid $(0-0.6 \mathrm{mg} / \mathrm{ml})$ standard calibration curve. Additional dilutions were performed when the absorbance value measured was determined to be over the linear range of the standard curve. The results were expressed as mg GAEs. All measurements were performed in triplicate and the mean values were calculated.

Determination of the total flavonoid content. The total flavonoid content was determined using the aluminum chloride 
colorimetric assay, as previously described (18). Briefly, distilled water (4 ml) was added to $1 \mathrm{ml} \mathrm{RJE}$, and subsequently $5 \%$ sodium nitrite solution $(0.3 \mathrm{ml}$; Sigma-Aldrich) was added, followed by $10 \%$ aluminium chloride solution $(0.3 \mathrm{ml}$; Sigma-Aldrich). The mixtures were incubated at room temperature for $5 \mathrm{~min}$, and $2 \mathrm{ml} 1 \mathrm{mM} / 1$ sodium hydroxide solution was subsequently added. The volume of the reaction mixture was made up to $10 \mathrm{ml}$ straight away with distilled water. The mixture was thoroughly vortexed and the absorbance of the pink color, which had developed, was determined at $510 \mathrm{~nm}$. A calibration curve was prepared using catechin as the reference compound and the results were expressed as mg catechin equivalents (CEs).

3-(4,5-dimethylthiazol-2-yl)-2,5-diphenyltetrazolium bromide (MTT) assay. The cytotoxicity of RJE in Chang liver cells was measured using an MTT assay. The assay is based on the cleavage of yellow tetrazolium salt dye into purple formazan by metabolically active cells, which can be photometrically quantified. An increase in the number of living cells results in an increase in total metabolic activity, which consequently leads to a higher formation of purple coloration. At $24 \mathrm{~h}$ following cell treatment, $20 \mu 1$ MTT dye $(5 \mathrm{mg} / \mathrm{ml})$ was added into each well and incubated for a duration of $4 \mathrm{~h}$. The medium was subsequently discarded and the intracellular formazan product was dissolved in $150 \mu \mathrm{l}$ DMSO. The absorbance of each well was measured at $540 \mathrm{~nm}$ using an enzyme-linked immunosorbent assay reader (Bio-Rad Model 680 Microplate reader; Bio-Rad, Hercules, CA, USA), and the cell viability was expressed as the percentage of the control cells.

Determination of SOD enzyme activity. The total proteins were extracted from cultured cells using Pro-Prep ${ }^{\mathrm{TM}}$ reagent (Intron Biotechnology, Inc., Seoul, South Korea) and the protein content was measured using a Bradford assay, with bovine serum albumin (BSA) as the standard. The level of SOD enzyme activity in the Chang liver cells was measured using a SOD determination kit (Sigma-Aldrich). Assays were performed in the manufacturer-provided 96-well plates. Briefly, samples $(10 \mu \mathrm{l})$ were added to $200 \mu \mathrm{l}$ diluted radical detector. The reaction was initiated by adding $20 \mu \mathrm{l}$ diluted xanthine oxidase (Sigma-Aldrich) to each well using a multichannel pipette. The plate was carefully agitated and incubated at room temperature for $20 \mathrm{~min}$. The absorbance was measured at $450 \mathrm{~nm}$ using a plate reader, and the SOD activity was expressed as U/mg cellular protein.

Determination of the CAT enzyme activity. The total proteins were extracted from cultured cells using Pro-Prep ${ }^{\mathrm{TM}}$ reagent (Intron Biotechnology, Inc.), and the protein content was measured using the Bradford assay, with BSA as the standard. The level of CAT enzyme activity in the Chang liver cells was measured using a CAT assay kit (Sigma-Aldrich). One unit of CAT was defined as the quantity of enzyme required to decompose $1 \mu \mathrm{M} \mathrm{H}_{2} \mathrm{O}_{2}$ in $1 \mathrm{~min}$. The rate of decomposition of $\mathrm{H}_{2} \mathrm{O}_{2}$ was measured spectrophotometrically at a wavelength of $570 \mathrm{~nm}$, and the enzyme activity was expressed as U/mg protein.

Cell cycle analysis. Chang liver cells were collected following treatments with RJE and $\mathrm{H}_{2} \mathrm{O}_{2}$, centrifuged (180 x g, $10 \mathrm{~min}$, $\left.4^{\circ} \mathrm{C}\right)$, resuspended in phosphate-buffered saline (PBS) and incubated with $80 \%$ ethyl alcohol overnight at $-4^{\circ} \mathrm{C}$, prior to further analysis. The cells were subsequently washed twice with PBS, suspended in $1 \mathrm{ml}$ cold propidium iodide (PI) solution (50 $\mu \mathrm{g} / \mathrm{ml}$ PI and $100 \mu \mathrm{g} / \mathrm{ml}$ ribonuclease). Subsequently, the cells were incubated on ice for $30 \mathrm{~min}$ in the dark prior to flow cytometric analysis using a Fluorescence-Activated Cell Sorting Calibur flow cytometry (BD Biosciences, Franklin Lakes, NJ, USA) and analyzed by Cell Quest software version 5.1 (BD Biosciences).

Western blot analysis. The total proteins were extracted from cultured cells using Pro-Prep ${ }^{\mathrm{TM}}$ reagent (Intron Biotechnology, Inc.) and stored at $-80^{\circ} \mathrm{C}$ until further use. Total protein concentration was determined using an Invitrogen ${ }^{\mathrm{TM}}$ Quant-iT protein assay kit (Thermo Fisher Scientific, Inc.). Equal amounts of protein $(20 \mu \mathrm{g})$ were separated using $10 \%$ sodium dodecyl sulfate-polyacrylamide gel electrophoresis (Sigma-Aldrich), and transferred onto nitrocellulose membranes (Bio-Rad). The membranes were subsequently blocked for $90 \mathrm{~min}$ at room temperature in Tris-buffered saline and Tween-20 buffer, comprising $20 \mathrm{mM}$ Tris- $\mathrm{HCl}$ ( $\mathrm{pH} 7.6), 135 \mathrm{mM}$ sodium chloride, $1 \%$ Tween-20 and 5\% non-fat dried milk. The blots were subsequently incubated at $4^{\circ} \mathrm{C}$ for $8 \mathrm{~h}$ separately with specific mouse monoclonal anti-p53 (1:1,000; cat. no. 554167; BD Biosciences), mouse monoclonal anti-Bax (1:1,000; cat. no. BS2538; Bioworld Technology, Inc., St. Louis Park, MN, USA), mouse monoclonal anti-caspase-3 (1:1,000; cat. no. 9661; Cell Signaling Technology, Inc., Danvers, MA, USA), and mouse monoclonal anti-Bcl-2 (1:1,000; cat. no. 610746; Santa Cruz Biotechnology, Inc., Santa Cruz, CA, USA) antibodies. Following incubation, the membrane was washed three times for $5 \mathrm{~min}$ in Tris-Buffered saline and Tween-20 buffer, prior to subsequent treatment with peroxidase-conjugated anti-rabbit immunoglobulin $\mathrm{G}$ antibody (Vector Laboratories, Inc., Burlingame, CA, USA) at a dilution of 1:1,000 for $\sim 2 \mathrm{~h}$ at room temperature. The membrane was washed and incubated with the substrate from an enhanced chemiluminescence reagent kit (DuPont NEN, Boston, MA, USA). The proteins were detected using a Fujifilm LAS-3000 Imager (Tokyo, Japan). As an internal control, the expression of $\beta$-actin was analyzed using a $\beta$-actin antibody $(1: 5,000$; cat. no. sc-1615; Santa Cruz Biotechnology, Inc.). In order to remove the antibodies and substrates, the blots were stripped using Restore ${ }^{\mathrm{TM}}$ Western Blot Stripping buffer (Thermo Fisher Scientific, Inc.), according to the manufacturer's protocol. Following stripping, the blot was reprobed with $\beta$-actin antibody to monitor the loading control.

Statistical analysis. The data were evaluated for statistical significance using SPSS 14.0 software for Windows (SPSS, Inc., Chicago, IL, USA). The data are expressed as the mean \pm standard error of the mean. The mean values were compared using a one-way analysis of variance, followed by Duncan's multiple-range test. $\mathrm{P}<0.05$ was considered to indicate a statistically significant difference.

\section{Results}

Effect of RJE on $\mathrm{H}_{2} \mathrm{O}_{2}$-induced cytotoxicity in the Chang liver cells. Initially, to investigate the RJE-induced cyto- 


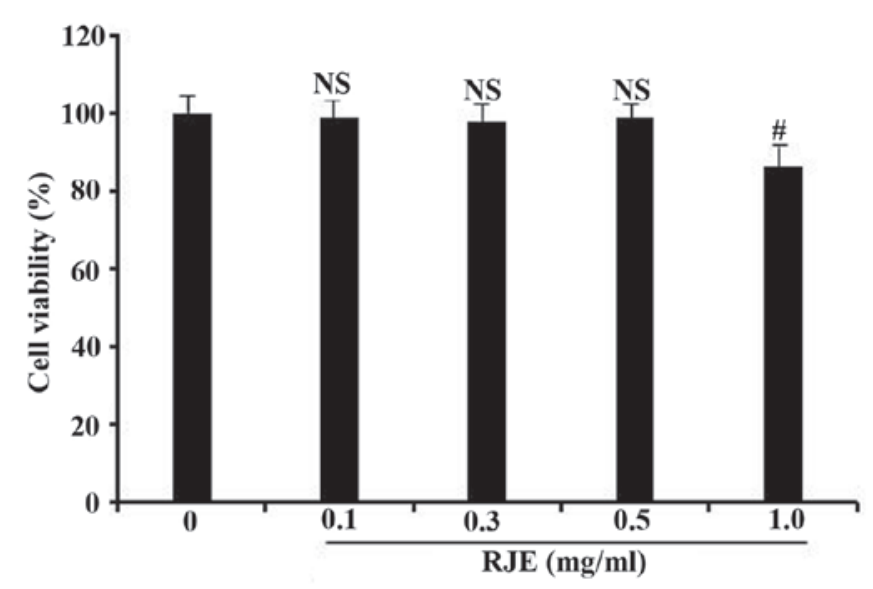

Figure 1. Effects of RJE on the cell viability of human Chang liver cells. The cytotoxicity of RJE in the Chang liver cells was measured using an MTT assay The data are expressed as the mean \pm standard error of the mean $\left(\mathrm{n}=6\right.$; ${ }^{\text {P }}<<0.05$, compared with the control cells). NS, not significant. RJE, Rhus javanica extract.

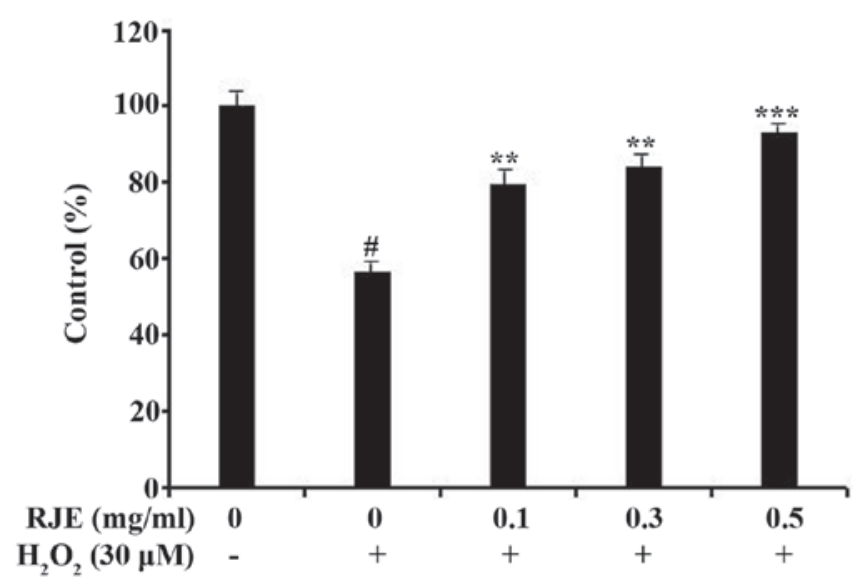

Figure 2. Effects of RJE on cell viability in $\mathrm{H}_{2} \mathrm{O}_{2}$-treated Chang liver cells. The cytotoxicity of RJE in Chang liver cells was measured using an MTT assay. The data are expressed as the mean \pm standard error of the mean $\left(\mathrm{n}=6\right.$; ${ }^{*} \mathrm{P}<0.05$, compared with control cells; ${ }^{* *} \mathrm{P}<0.01$ and ${ }^{* * *} \mathrm{P}<0.001$, compared with $\mathrm{H}_{2} \mathrm{O}_{2}$-treated cells using a one-way analysis of variance test followed by Duncan's multiple-range test). $\mathrm{H}_{2} \mathrm{O}_{2}$, hydrogen peroxide; RJE, Rhus javanica extract.

toxicity of the cells, Chang liver cells were exposed to RJE at concentrations of $0,0.1,0.3,0.5$ or $1.0 \mathrm{mg} / \mathrm{ml}$ for $24 \mathrm{~h}$, and the cytotoxicity was determined using an MTT assay. As shown in Fig. 1, RJE exhibited no signs of cytotoxicity up to a concentration of $0.5 \mathrm{mg} / \mathrm{ml}$. Therefore, the subtoxic concentrations of $0.1,0.3$ and $0.5 \mathrm{mg} / \mathrm{ml}$ were selected for subsequent experiments. $\mathrm{H}_{2} \mathrm{O}_{2}(30 \mu \mathrm{M})$ significantly $(\mathrm{P}<0.05)$ reduced the cell viability of Chang liver cells (Fig. 2). However, RJE pretreatment (at concentrations of $0.1,0.3$ or $0.5 \mathrm{mg} / \mathrm{ml})$ significantly $(\mathrm{P}<0.05, \mathrm{P}<0.01$ and $\mathrm{P}<0.001$ for $0.1,0.3$ and $0.5 \mathrm{mg} / \mathrm{ml}$, respectively) inhibited in a concentration-dependent manner the cytotoxicity induced by $\mathrm{H}_{2} \mathrm{O}_{2}$ in Chang liver cells (Fig. 2).

RJE enhances the $\mathrm{H}_{2} \mathrm{O}_{2}$-induced CAT and SOD activity in Chang liver cells. It is well known that the activity of endogenous antioxidant enzymes, including CAT and SOD, protects
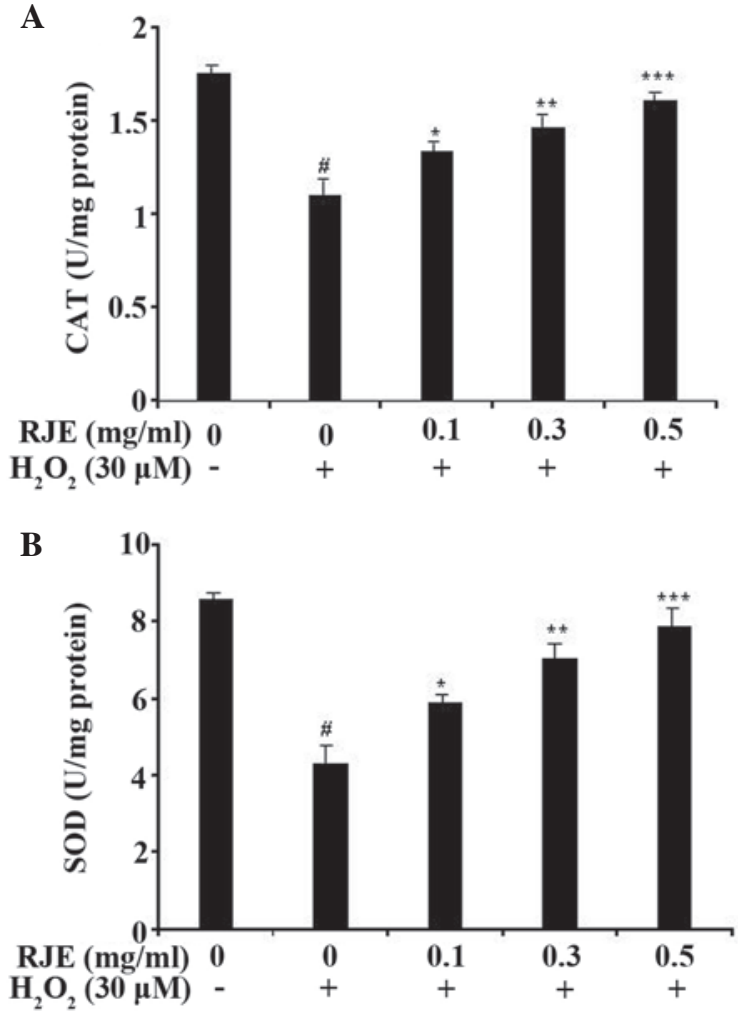

Figure 3. Effects of RJE on the activity of (A) CAT and (B) SOD in $\mathrm{H}_{2} \mathrm{O}_{2}$-treated Chang liver cells. The SOD and CAT enzyme activity levels in the Chang liver cells were measured using a SOD and CAT determination kit, respectively The data are expressed as the mean \pm standard error of the mean $\left(\mathrm{n}=6\right.$; ${ }^{*} \mathrm{P}<0.05$, compared with control cells; ${ }^{*} \mathrm{P}<0.05,{ }^{* *} \mathrm{P}<0.01$ and ${ }^{* * * *} \mathrm{P}<0.001$, compared with $\mathrm{H}_{2} \mathrm{O}_{2}$-treated cells using a one-way analysis of variance, followed by Duncan's multiple-range test). CAT, catalase; $\mathrm{H}_{2} \mathrm{O}_{2}$, hydrogen peroxide; RJE, Rhus javanica extract; SOD, superoxide dismutase.

cells from ROS-induced oxidative damage $(4,5)$. In order to investigate whether RJE was mediated by the activities of antioxidant enzymes, CAT and SOD enzyme activities were measured in $\mathrm{H}_{2} \mathrm{O}_{2}$-damaged Chang liver cells. $\mathrm{H}_{2} \mathrm{O}_{2}(30 \mu \mathrm{M})$ significantly $(\mathrm{P}<0.05)$ decreased the activities of CAT and SOD compared with the control cells. However, RJE-treated groups increased the enzyme activity of CAT and SOD in a concentration-dependent manner (Figs. 3A and B). Treatment of the cells with RJE at a concentration of $0.5 \mathrm{mg} / \mathrm{ml}$ attenuated the $\mathrm{H}_{2} \mathrm{O}_{2}$-induced suppression of CAT and SOD enzyme activities to almost normal levels $(\mathrm{P}<0.001)$. These results supported the hypothesis that RJE protects Chang liver cells from $\mathrm{H}_{2} \mathrm{O}_{2}$-induced cytotoxicity by increasing the levels of the endogenous antioxidant enzymes.

Effect of RJE on the cell cycle in $\mathrm{H}_{2} \mathrm{O}_{2}$-induced Chang liver cells. The flow cytometric analysis of the $\mathrm{H}_{2} \mathrm{O}_{2}$-treated cells, treated with or without RJE, is shown in Fig. 4A. A significant effect $(\mathrm{P}<0.001)$ was observed on treatment of the cells with 0.3 and $0.5 \mathrm{mg} / \mathrm{ml} \mathrm{RJE}$, with 3.09 and $2.02 \%$ of the cells being counted in the sub-growth $(\mathrm{G})_{1}$ phase, respectively, compared with the $\mathrm{H}_{2} \mathrm{O}_{2-}$ treated cells without RJE treatment ( $44.86 \%$ of the cells counted in the sub- $\mathrm{G}_{1}$ phase; Fig. $4 \mathrm{~B}$ ). These results suggested that RJE treatment exerted a marked effect by reducing the death of the Chang liver cells. 


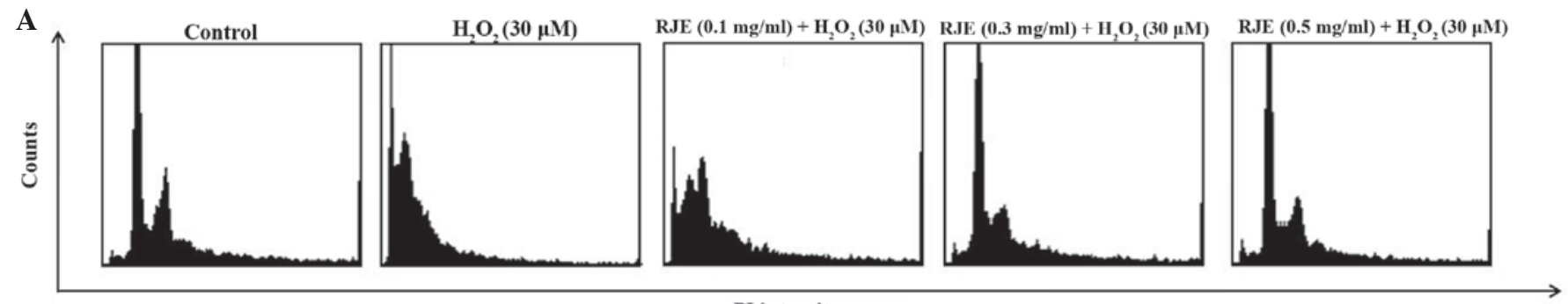

PI intensity

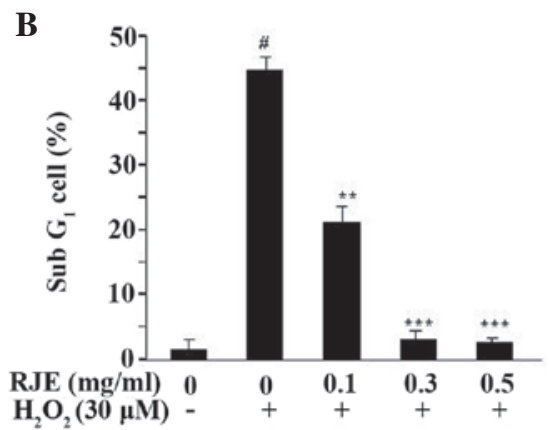

Figure 4. Effects of RJE on the cell cycle in $\mathrm{H}_{2} \mathrm{O}_{2}$-treated Chang liver cells. The DNA content in different phases of the cell cycle was measured using PI staining and determined by flow cytometric analysis. (A) The cell cycle distribution, and (B) the percentage of sub- $\mathrm{G}_{1}$ cell cycle data were determined. The data are expressed as the mean \pm standard error of the mean $\left(\mathrm{n}=6 ;{ }^{*} \mathrm{P}<0.05\right.$, compared with control cells; ${ }^{* *} \mathrm{P}<0.01$ and ${ }^{* * *} \mathrm{P}<0.001$, compared with $\mathrm{H}_{2} \mathrm{O}_{2}$-treated cells using a one-way analysis of variance test followed by Duncan's multiple-range test). $\mathrm{G}_{1}$, growth phase $1 ; \mathrm{H}_{2} \mathrm{O}_{2}$, hydrogen peroxide; PI, propidium iodide; RJE, Rhus javanica extract.

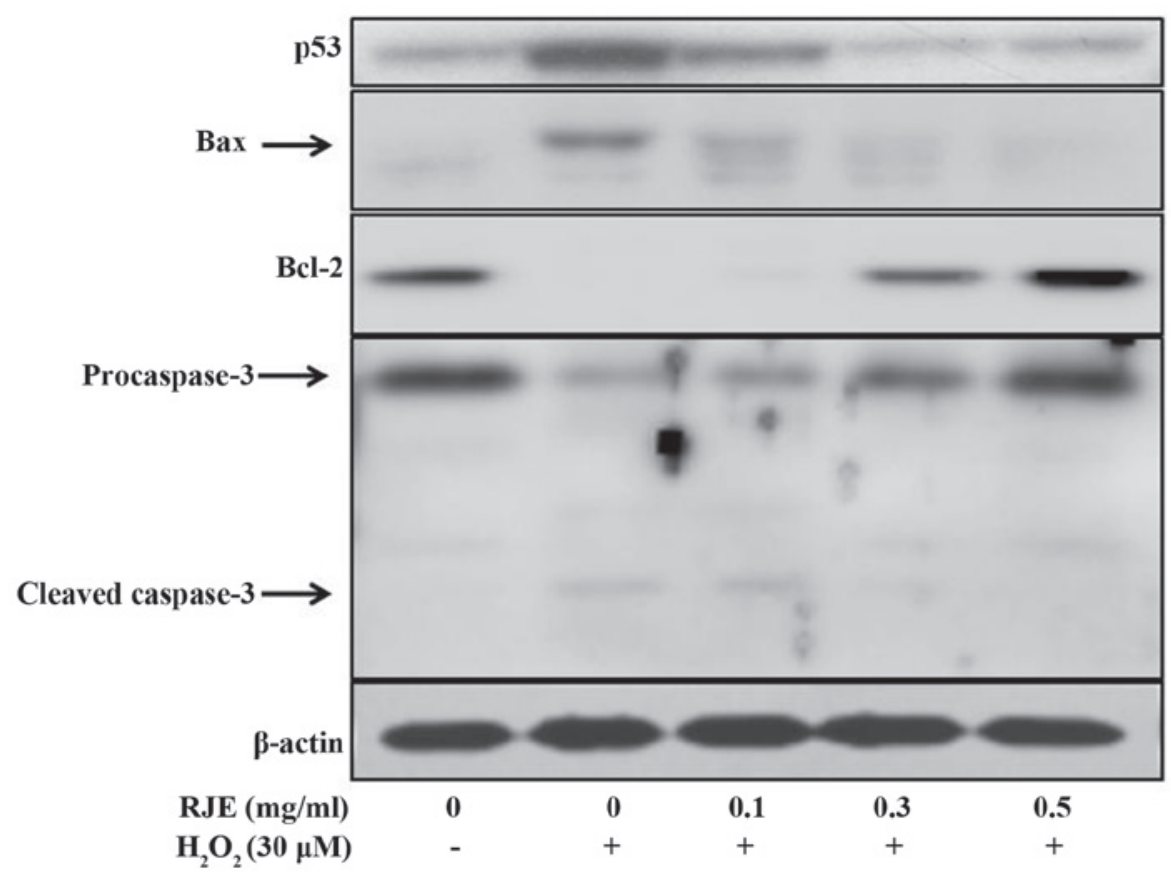

Figure 5. Effects of RJE on the expression of apoptotic signaling molecules in $\mathrm{H}_{2} \mathrm{O}_{2}$-treated Chang liver cells. The expression levels of apoptotic signaling molecules, including p53, Bax, Bcl-2 and caspase-3, in $\mathrm{H}_{2} \mathrm{O}_{2}$-induced Chang liver cells was analyzed by western blotting using specific antibodies against the target proteins. $\beta$-actin was used as an internal loading control. $\mathrm{H}_{2} \mathrm{O}_{2}$, hydrogen peroxide; RJE, Rhus javanica extract; Bcl, B-cell lymphoma; Bax, $\mathrm{Bcl}$-associated $\mathrm{X}$ protein.

Antioxidant potential of RJE in FRAP and ABTS free radical scavenging assay. The antioxidant capacity of RJE was determined using the ABTS method and the FRAP assay. With the ABTS assay, an inhibition of the generation of the $\mathrm{ABTS}^{-+}$radical cation provides the basis of the spectrophotometric method, which may be applied in order to measure the total antioxidant activities of solutions of pure substances, aqueous mixtures and beverages. Trolox was used as a positive control. The total antioxidant activity was expressed as the mM Trolox equivalent antioxidant capacity, by reference to the Trolox standard calibration curve. The ABTS radical scavenging activity was determined to 
be $0.93 \pm 0.06 \mathrm{mM}$ Trolox equivalents $/ \mathrm{mg}$ extract, and that of BHT was $0.94 \pm 0.02 \mathrm{mM}$ Trolox equivalents/mg dry weight.

Furthermore, the FRAP assay was used, as it is quick and simple to perform, and the reaction is reproducible and linearly correlated with the molar concentration of the antioxidants (19). The ferric reducing antioxidant power of RJE was expressed as the $\mathrm{mM}$ ferrous iron equivalents per mg dry weight of RJE. The antioxidant activity of RJE using FRAP assay was determined to be $0.88 \pm 0.09 \mathrm{mM} \mathrm{FeSO}_{4}$ equivalents $/ \mathrm{mg}$ extract, and $1.88 \pm 0.16 \mathrm{mM} \mathrm{FeSO}_{4}$ equivalents/mg dry weight for BHT. These results indicated that RJE exhibited antioxidant effects.

Determination of the total polyphenol and flavonoid content in RJE. Polyphenols, including flavonoids, have received considerable attention due to their marked antioxidant activities (20). Therefore, we measured the total polyphenolic and flavonoid content in RJE. The quantity of the total polyphenol and flavonoid content in RJE was determined to be $56.12 \pm 0.06 \mathrm{mg}$ GAEs/g extract and $47.5 \pm 2.33 \mathrm{mg} \mathrm{CEs} / \mathrm{g}$ extract, respectively.

Effect of RJE on the expression levels of apoptotic signaling molecules in $\mathrm{H}_{2} \mathrm{O}_{2}$-induced Chang liver cells. ROS induce a variety of physiological and cellular events, including DNA damage and apoptosis. Several genes exert important roles in apoptotic pathways. The p53 gene is able to activate the cell cycle checkpoint, DNA repair and apoptosis. The ratio of Bax protein to Bcl-2 protein functions as a cell death 'switch'. Therefore, the present study investigated the effect of RJE on $\mathrm{H}_{2} \mathrm{O}_{2}$-induced apoptotic signaling mediators in Chang liver cells. As shown in Fig. 5, RJE treatment regulated the protein expression levels of the apoptotic genes in $\mathrm{H}_{2} \mathrm{O}_{2}$-induced cytotoxicity in Chang liver cells. The expression levels of proapoptotic proteins, including p53, Bax and cleaved caspase-3, were downregulated, whereas the expression level of the antiapoptotic protein, Bcl-2, was markedly upregulated. These results, therefore, provided the evidence that RJE reduced apoptosis in Chang liver cells via a decrease in the protein expression levels of p53, Bax and cleaved caspase-3, and an increase in the protein expression of Bcl-2.

\section{Discussion}

Oxidative stress, which is produced by ROS, provides one of the major determining factors of cellular injuries in a variety of aberrant clinical conditions, including hepatoprotection (21). In the present study, RJE elicited protective effects against $\mathrm{H}_{2} \mathrm{O}_{2}$-induced cytotoxicity via an inhibition of the generation of intracellular ROS in Chang liver cells. The natural antioxidant system comprises various antioxidant compounds and antioxidant enzymes, including SOD, CAT and glutathione peroxidase. ROS is converted into $\mathrm{H}_{2} \mathrm{O}_{2}$ by SOD. $\mathrm{H}_{2} \mathrm{O}_{2}$, in turn, is converted into molecular oxygen and $\mathrm{H}_{2} \mathrm{O}$ by CAT (22). In addition, previous studies indicated that CAT is considered to be the most important enzyme involved in the detoxification of $\mathrm{H}_{2} \mathrm{O}_{2}$ and the protection of hepatocytes from oxidative stress (23). In the present study, the decreased enzyme activity of SOD and CAT upon $\mathrm{H}_{2} \mathrm{O}_{2}$ induction was markedly increased in RJE-treated Chang liver cells. These results supported the hypothesis that RJE protected Chang liver cells from $\mathrm{H}_{2} \mathrm{O}_{2}$-induced cytotoxicity by regulating the activities of the intracellular antioxidative enzymes.

The cell cycle comprises a series of events, which occur in a cell, leading to its division and replication, thereby producing two daughter cells. It is divided into four different phases: Synthesis (S) phase (chromosomal replication), mitotic (M) phase (chromosomal condensation and separation), $\mathrm{G}_{1}$ phase (existing between $M$ phase and $S$ phase) and $\mathrm{G}_{2}$ phase (existing between $\mathrm{S}$ phase and $\mathrm{M}$ phase). The predominant control point of the cell cycle is situated in the late $G_{1}$ phase. As shown in the present study, the increased sub- $\mathrm{G}_{1}$ phase associated with $\mathrm{H}_{2} \mathrm{O}_{2}$ cytotoxicity was reduced by treatment with $\mathrm{RJE}$, indicating that $\mathrm{RJE}$ may inhibit $\mathrm{H}_{2} \mathrm{O}_{2}$-induced apoptosis in Chang liver cells.

$\mathrm{H}_{2} \mathrm{O}_{2}$ leads to a variety of physiological and cellular events, including inflammation, DNA damage and apoptosis. Apoptosis is induced by extracellular or intracellular signals, which trigger the onset of a signaling cascade characterized by specific biochemical and cytological signatures, including nuclear condensation and DNA fragmentation (24). Several genes are known to be involved in apoptotic pathways. The p53 gene activates cell cycle checkpoints, DNA repair and apoptosis to maintain genomic stability (25). The ratio of Bax to Bcl-2 functions as a cell death 'switch', which determines whether cells live or die in response to an apoptotic stimulus. An increased $\mathrm{Bax} / \mathrm{Bcl}-2$ ratio decreases the cellular resistance to apoptotic stimuli, leading to apoptosis $(26,27)$. Furthermore, destabilization of the mitochondrial integrity by apoptotic stimuli precedes activation of caspases, leading to apoptosis $(28,29)$. Several genes, including those for p53, Bax, Bcl-2 and caspase-3, are known to be involved in the apoptotic pathway (30). In the present study, the increased protein expression levels of p53, proapoptotic Bax and caspase-3 in the $\mathrm{H}_{2} \mathrm{O}_{2}$-induced Chang liver cells were inhibited on treatment with RJE. By contrast, the decreased expression of the antiapoptotic protein, Bcl-2, was increased in Chang liver cells compared with $\mathrm{H}_{2} \mathrm{O}_{2}$-treated cells. These results provided evidence that RJE inhibited $\mathrm{H}_{2} \mathrm{O}_{2}$-induced apoptosis.

The use of numerous herbal and other natural products worldwide for the prevention and treatment for oxidation is gaining in popularity. According to the Illustrated Book of Korean Medicinal Herbs (12), each component part of the $R$. javanica plant is associated with various medicinal efficacies. In particular, $R$. javanica exerts liver protection and detoxification effects (12). Previous phytochemical studies on RJE revealed the presence of several polyphenolic constituents, including gallic acid, triterpenes and semialactic acid $(11,31)$. These compounds have been previously described to possess antioxidant properties $(11,32,33)$. The data in the present study concurred with the previously published studies that RJE exhibits marked antioxidant activity, as determined by the ABTS free radical scavenging assay and the FRAP assay. The present study also demonstrated that RJE has phenolic content.

In conclusion, the present study indicated that RJE exhibited marked protective effects against $\mathrm{H}_{2} \mathrm{O}_{2}$-induced cytotoxicity and oxidative stress in human Chang liver cells. Treatment of the cells with RJE enhanced the activities of the antioxidative enzymes, including SOD and CAT. Furthermore, changes in the levels of the $\mathrm{H}_{2} \mathrm{O}_{2}$-induced 
apoptotic signaling genes were regulated by RJE in the Chang liver cells. RJE also exhibited marked antioxidant capacity, as determined by the ABTS and the FRAP assays. The putative antioxidant compounds present in the extract may act individually or in combination in delivering such beneficial effects, thereby providing insights into the mechanism which underpins traditional claims made for RJE in the treatment of oxidative stress-mediated hepatic diseases.

\section{Acknowledgements}

The present study was supported by Konkuk University in 2015 .

\section{References}

1. Saladin KS: Anatomy \& Physiology: The Unity of Form and Function (6th ed.), The McGraw-Hill Companies, USA, 887-925, 2011.

2. Muriel P: Role of free radicals in liver diseases. Hepatol Int 3: 526-36, 2009.

3. Nordberg J and Arnér ES: Reactive oxygen species, antioxidants, and the mammalian thioredoxin system. Free Radic Biol Med 31:1287-1312, 2001.

4. Medina J and Moreno-Otero R: Pathophysiological basis for antioxidant therapy in chronic liver disease. Drugs 65: 2445-2461, 2005.

5. Cerella C, Coppola S, Maresca V, De Nicola M, Radogna F and Ghibelli L: Multiple mechanisms for hydrogen peroxide-induced apoptosis. Ann N Y Acad Sci 1171: 559-563, 2009.

6. Clément MV, Ponton A and Pervaiz S: Apoptosis induced by hydrogen peroxide is mediated by decreased superoxide anion concentration and reduction of intracellular milieu. FEBS Lett 440: 13-18, 1998.

7. Kim MH, Chung J, Yang JW, Chung SM, Kwag NH and Yoo JS: Hydrogen peroxide-induced cell death in a human retinal pigment epithelial cell line, ARPE-19. Korean J Ophthalmol 17: 19-28, 2003.

8. Sharma A, Chakraborti KK and Handa SS: Anti-hepatotoxic activity of some Indian herbal formulations as compared to silymarin. Fitoterapia 62: 229-235, 1991.

9. Britton RS and Bacon BR: Role of free radicals in liver diseases and hepatic fibrosis. Hepatogastroenterology 41: 343-348, 1994.

10. Cha BC, Lee SB, Rhim TJ and Lee KH: Constituents of antioxidative activity and free radical scavenging effect from Galla Rhois (Rhus javanica Linne). Korean J Pharmacogn 31: 185-189, 2000.

11. Lee IS, Oh SR, Ahn KS and Lee HK: Semialactone, isofouquierone peroxide and fouquierone, three new dammarane triterpenes from Rhus javanica. Chem Pharm Bull (Tokyo) 49: 1024-1026, 2001.

12. Ahn DK: Illustrated Book of Korean Medicinal Herbs. Kyo-Hak Publisher, Seoul, South Korea, 1998.

13. You YO, Choi NY, Kang SY and Kim KJ: Antibacterial Activity of Rhus javanica against Methicillin-Resistant Staphylococcus aureus. Evid Based Complement Alternat Med 2013: 549207, 2013.
14. Djakpo O, Yao W: Rhus chinensis and Galla chinensis - folklore to modern evidence: Review. Phytother Res 24: 1739-1747, 2010.

15. Szeto YT, Chu WK and Benzie IFF: Antioxidants in fruits and vegetables: A study of cellular availability and direct effects on human DNA. Biosci Biotechnol Biochem 70: 2551-2555, 2006.

16. Re R, Pellegrini N, Proteggente A, Pannala A, Yang M and Rice-Evans C: Antioxidant activity applying an improved ABTS radical cation decolorization assay. Free Radic Biol Med 26: 1231-1237, 1999.

17. Wolfe K, Wu X and Liu RH: Antioxidant activity of apple peels. J Agric Food Chem 51: 609-614, 2003.

18. Kim DO, Jeong SW and Lee CY: Antioxidant capacity of phenolic phytochemicals from various cultivars of plums. Food Chem 81: 321-326, 2003.

19. Muller L, Gnoyke S, Popken AM and Bohm V: Antioxidant capacity and related parameters of different fruit formulations. LWT-Food Sci Technol 43: 992-999, 2010.

20. Othman A, Ismail A, Ghani AN and Adenan I: Antioxidant capacity and phenolic content of cocoa beans. Food Chem 100: 1523-1530, 2007

21. Zhang R, Kang KA, Piao MJ, Kim KC, Kim AD, Chae S, Park JS, Youn UJ and Hyun JW: Cytoprotective effect of the fruits of Lycium chinense Miller against ox idative stress-induced hepatotoxicity. J Ethnopharmacol 130: 299-306, 2010.

22. Sindhu RK, Koo JR, Roberts CK and Vaziri ND: Dysregulation of hepatic superoxide dismutase, catalase and glutathione peroxide in diabetes: Response to insulin and antioxidant therapies. Clin Exp Hypertens 26: 43-53, 2004.

23. De Bleser PJ, Xu G, Rombouts K, Rogiers V and Geerts A: Glutathione levels discriminate between oxidative stress and transforming growth factor-beta signaling in activated rat hepatic stellate cells. J Biol Chem 274: 33881-33887, 1999.

24. Gopinath P, Gogoi SK, Sanpui P, Paul A, Chattopadhyay A and Ghosh SS: Signaling gene cascade in silver nanoparticle induced apoptosis. Colloids Surf B Biointerfaces 77: 240-245, 2010.

25. Sherr CJ: Principles of tumor suppression. Cell 116: 235-246, 2004.

26. Chiu CL, Lee TH, Shao YY and Kuo YH.: Three new triterpenes from the roots of Rhus javanica L. var. roxburghuna. J Asian Nat Prod Res 10: 684-688, 2008.

27. Gao C and Wang AY: Significance of increased apoptosis and Bax expression in human small intestinal adenocarcinoma. J Histochem Cytochem 57: 1139-1148, 2009.

28. Timmer JC and Salvesen GS: Caspase substrates. Cell Death Differ 14: 66-72, 2007.

29. Youle RJ and Strasser A: The Bcl-2 protein family: Opposing activities that mediate cell death. Nat Rev Mol Cell Biol 9: 47-59, 2008.

30. Ahmad J, Ahamed M, Akhtar MJ, Alrokayan SA, Siddiqui MA, Musarrat J and Al-Khedhairy AA: Apoptosis induction by silica nanoparticles mediated through reactive oxygen species in human liver cell line HepG2. Toxicol Appl Pharmacol 259: $160-168,2012$

31. Chung SC, Hwang BY, Oh GJ, Kang SJ, Kim MJ, Choi WH, Lee KS and Ro JS: Chemical components from the stem bark of Rhus javanica L. Kor J Pharmacogn 30: 295-300, 1999.

32. Aruoma O, Murcia A, Butler J and Halliwell B: Evaluation of the antioxidant and prooxidant actions of gallic acid and its derivatives. J Agric Food Chem 41: 1880-1885, 1993.

33. Devbhuti P, Roy S, Sarkar RG and Devbhut D: An in vitro study on effect of lactic acid and ascorbic acid on etoposide-induced lipid peroxidation. J Pharma Sci Technol 2: 91-95, 2013. 